\title{
Using Community Service Learning to Develop the Writing Skills of Engineering Students
}

\author{
Kim Davis \\ Instructor, School of Linguistics \\ and Language Studies \\ Carleton University \\ kim_davis@carleton.ca \\ Helen Triantafellou \\ Instructor, School of Linguistics \\ and Language Studies \\ Carleton University \\ helen_triantafellou@carleton.ca
}

\author{
Lisa Meyer \\ Instructor, School of Linguistics \\ and Language Studies \\ Carleton University \\ lisa_meyer@carleton.ca
}

\begin{abstract}
In our Engineering Communication Skills classrooms we aim to provide a meaningful setting in which students move from the classroom sphere to the professional sphere of writing. In this paper, we report on how we can use community service learning (CSL) to bridge these two spheres of writing. We show how the necessity of effective communication with community-based clients leads to audience awareness and subsequent acquisition of professional Engineering communication skills.
\end{abstract}

\section{Introduction}

The "Communication Skills for Engineering Students" courses we offer at Carleton University are designed to teach students to adapt their communication skills to new contexts and audiences (beyond the classroom), and thus ultimately be able to communicate successfully as professional engineers. To give our students the opportunity to communicate with community members, we designed Community Service Learning (CSL) projects for two of our courses in Fall 2010 based on Purdue University's Engineering Projects in Community Service (EPICS) program [1], where Engineering students work with 
community partners to improve upon their existing products or services, or create new ones. In this paper, we define CSL and describe its benefits, discuss how we feel our CSL projects can contribute to the acquisition of Engineering communication (specifically writing) skills, and finally provide recommendations for effective use of CSL projects in communication skills courses.

\section{Description of CSL}

\subsection{Community Service Learning Defined}

CSL is a unique form of experiential learning. The underlying difference between CSL opportunities and other experiential approaches to learning is that CSL opportunities benefit both the student and the recipient of the service; a service is provided while at the same time learning is occurring [2]. Furthermore, CSL programs, unlike volunteer programs, must have some type of academic context [3]. The key to CSL is that the learning experiences are wellconnected with the course material in a way that the engagement with the course material aids in more successful and effective comprehension of the content matter being taught [4].

\subsection{Benefits of Community Service Learning on Post-Secondary Studies}

There is a growing body of literature which documents the benefits of CSL during undergraduate studies [5][6][7]. Four benefits discussed here are 1) more effective learning, 2) student engagement and retention, 3) creation of a bridge between university and workplace writing, and 4) development of stronger writing skills.

\subsubsection{More effective learning}

CSL projects lead to more successful learning, given the belief that learning occurs through coparticipation in a process [8]. "Experience in and of itself is not educative unless it is ...linked with efforts to move beyond individual experience to consideration of larger social processes" [9,p. 78]. Learning is social and happens when communication occurs while working towards a practical goal. [10].

\subsubsection{Student engagement and retention}

CSL has been found to lead to increased student engagement, improved academic outcomes and ultimately, to increased rates of retention [11][5][4][12][13]. There appears to be a correlation between CSL and increased personal and social awareness, and improved student learning outcomes that 
ultimately engage and retain students in post-secondary institutions [13]. For example, a study of the EPICS program at Purdue University suggested that women in the fields of Science and Engineering are attracted to and more engaged in learning situations in which there are personal interactions, hands-on learning with real applications and authentic contexts [14].

\subsubsection{Creation of a bridge between university and professional writing}

Learning to write for and in university is very different from learning to write in the workplace. In the university, students are taught to write. In the workplace, on the other hand, learning to write is incidental, as learners act in a community of practice (COP) [15] to achieve a goal [8]. The genre features are a manifestation of the knowledge which an organization possesses which allows it to function as a group [16]. The genres reflect the routines / habitual practices of the group. As newcomers are socialized into the $\mathrm{COP}$, they acquire the genre of that COP.

Secondly, the social motives of workplace writing and university writing are very different. In the workplace a COP focuses on what people do; the purpose of the communication/ writing is to get the work done. The texts are the tools [8,p.83], and are a component of how the knowledge of an organization is created, developed, shared [17]. In the university, on the other hand, the main social motive is grading.

Thirdly, writing in the workplace is much more complex. "...[M]ost workplace authors follow a host of implicit and explicit rhetorical rules [8,p. 115]." Texts in the workplace are part of a complex activity system [18]. Texts are "but one strand in an intricate network of events, intentions, other texts, relationships and readers [8,p.113]." Potential readers are many and often indeterminate, and these readers will have different purposes for reading these texts. In the university, on the other hand, a student text is typically written in isolation, for one reader.

Fourthly, much workplace writing is collaborative. In university, students are used to performing and being judged as individuals, and need to learn that workplace activities and texts depend much more on collaboration.

Therefore, if we want our students to acquire workplace communication skills, they need to be immersed in a workplace setting or scenario which features the "untidy" nature of workplace participation [8,p.192]. A CSL project gives students a glimpse into the socially complex nature of professional communication. 


\subsubsection{Acquisition of better writing skills}

CSL results in better writing skills firstly because students are more motivated. Not just grades are at stake; there are real consequences involved. Students reported that through working on CSL writing projects they were able to see how to apply their writing skills to real life, and that they therefore felt they had a valid and meaningful reason for doing their assignments. Secondly, students are forced to be more sensitive to the needs of their audience [19]. “...[W]riters develop language and discourse skills best by writing for a variety of audiences, not only for the teacher [20,p.80]".

\section{CSL Project Use in Engineering Communication Courses at Carleton University}

\subsection{CSL Project Descriptions}

We incorporated CSL projects into two of our Engineering courses: Communication Skills for Engineering Students (CCDP2100) and Communication Skills for Interactive Multimedia Design (IMD3003) in the Fall 2010 term.

\section{CSL Project in IMD3003}

IMD3003 students were asked to produce short documentary films about organizations which are supported by and/or are members of
Transition Ottawa ${ }^{1}$. The purpose of the films was to publicize to youth the messages and activities of the organizations.

\section{CSL Project in CCDP2100}

Sustainable Living Ottawa East $(\mathrm{SLOE})^{2}$ requested that students conduct electricity audits for homeowners in their community and provide recommendations on how these residents could reduce their electricity use.

\subsection{Benefits of CSL Projects in Engineering Courses}

\subsubsection{Improved writing skills}

In both courses, students were required to write documents for a variety of audiences: the Transition Ottawa representative, the homeowners, organizations being featured in the students' films, and the course instructor. Students had to carefully consider their readers' needs and level of knowledge, which affected the resultant content, style

\footnotetext{
${ }^{1}$ Transition Ottawa is a non-profit organization that has a goal of creating a sustainable and supportive city [21][22].
}

${ }^{2}$ SLOE is a community organization which works towards developing a greener community with projects such as home electricity audits [23] [24]. 
and tone of their documents. Success depended on a student's ability to 1 . accurately assess these elements in the writing context, and 2. respond accordingly in their documents. Students came to realize, from necessity, that they needed to adapt their writing content and style depending on the audience.

\subsubsection{Benefits noted by students}

According to our students, working with a client was a positive real-life experience which helped prepare them for their future careers.

"Learning how and practicing communication with different audiences is essential to one's experience in life." [CCDP student]

"This (CSL learning) is valuable because regular learning always deals with hypothetical situations and doesn't allow us to effectively prepare for situations we might encounter as part of our jobs." [CCDP student]

\subsection{Challenges and Recommendations for Improvement of CSL Projects}

Given the challenges that course instructors and students faced with our CSL projects, the following recommendations should help improve the effectiveness of such projects.

1) There needs to be a clear understanding of the relevance of the final product to the objectives of the course.

Some students struggle to see the relevance of the work they put into producing a final product for their community partner. It needs to be made very clear to students that a successful final product depends on the effectiveness of their communication throughout the project.

2) Students need to be prepared for working with communitybased clients.

The importance of a professional and respectful student-client relationship needs to be emphasized at the outset of the project.

3) There needs to be sufficient contact between students and clients throughout the term.

Students need to be involved enough with the community partner (client) to feel they can "observe and participate in the practice of a community" [8, p.30]. Clients need to be willing to invest adequate time in guiding students throughout the project.

Course instructors should ensure that the client responds to students' emails with constructive feedback. Teams who did not receive enough feedback and wondered about the quality of their assignments, were uncertain, unhappy and indifferent with respect to the quality of the final product. These teams perceived the lack of constructive feedback as lack 
of support from the client. Such perceptions had a negative impact on their views of the entire course and the relevance of the communitybased project to the course objectives.

"With ... the work being done for free, they (clients) don't ever seem all that concerned about the whole affair as they may or not use the end result, and it doesn't really matter cause if it were really crucial to them and they really needed it done they would have paid somebody. ... It's just the nature of the relationship when money is not involved and everything is done basically on a volunteer basis" [IMD student].

In the case of IMD3003, the lack of constructive feedback from the client resulted in lack of effective communication between student teams and the client, and, therefore, inability to practice communication skills as expected in a communications skills course.

\section{4)There needs to be sufficient incentive for students to produce quality work for the client.}

The films produced by the IMD3003 students were worth only $5 \%$, to encourage them to focus more on the accompanying written documents; however, students pointed out the following problem with this grade weightage.

"If something is worth only 5\% then only $5 \%$ of our time is going to be put into working on it. Consequently, ... this video is not ... something I'd want to put in a portfolio and not something that would really impress the client" [IMD3003 student].

The product should be worth enough to award students for the skills that they bring to the project. We suggest requiring students to produce a less time consuming final product so that they would have enough time to produce an end-product that they could use as a portfolio piece.

6)Students need to reflect on the process they are experiencing in the CSL project.

It is important that what students are learning about the acquisition of new genres is transferable to another setting, another project. It will more likely be transferable if students have articulated their experiences at an explicit level.

\section{7)Evaluators and evaluation criteria for project documents must be established, and made clear to students.}

\section{Conclusion}

We recommend the use of CSL projects for helping Engineering students acquire professional communication skills. Successful communication is a necessary tool for project success, a tool students master as they acquire audience awareness and adopt professional genres. 


\section{References}

[1] Purdue University, EPICS Purdue, https://engineering.purdue.edu/EPICS/Ab out Accessed Jan. 11, 2011.

[2] A. Furco, "Service-learning: A Balanced Approach to Experiential Education", Expanding Boundaries: Service and Learning, 2-6, Washington DC: Corporation for National Service, http://www.ucalgary.ca/servicelearning/fi les/servicelearning/Furco_1996_A_Balan ced_Approach.pdf Accessed May 2, 2011.

[3] Canadian Alliance of Community Service Learning (CACSL), www.communityservicelearning.ca

Accessed March 18, 2010.

[4] L.S. O'Hara, "Service-learning: Students' Transformative Journey from Communication Student to Civic-Minded Professional", Southern Communication Journal, 66: 3, pp. $251-266,2001$.

[5] A. Astin, L. Vogelgesang, E. Ikeda, and J. Yee, How Service Learning Affects Students, Higher Education Research Institute, UCLA, 2000.

[6] J.L. Singleton, "Taking the Class to the Community with Service-Learning", Journal of Gerontological

Social Work, 50: 1, pp.105 - 118, 2007.

[7] J. Eyler, D. Giles,C. Stenson, C., and

C. Gray, "At a Glance: What We Know about the Effects of Service-Learning on College Students, Faculty, Institutions and Communities", 1993-2000: $3^{\text {rd }}$ ed., 2001,

http://servicelearning.org/filemanager/do wnload/aag.pdf Accessed April 30, 2011.

[8] P. Dias, A. Freedman, P. Medway and A. Pare, Worlds Apart: Acting and Writing in Academic and Workplace Contexts, Lawrence Erlbaum Associates, Mahwah, NJ/London, 1999.

[9] D.D. Cooper, David D. and L. Julier,
"Writing the Ties that Bind: ServiceLearning in the Writing Classroom", Michigan Journal of Community Service Learning 2:1, pp. 72-85, 1995, Available at

http://quod.lib.umich.edu/cgi/t/text/pagev iewer-

$\mathrm{idx} ? \mathrm{c}=\mathrm{mjcsl} ; \mathrm{cc}=\mathrm{mjcsl} ; \mathrm{view}=$ image $; \mathrm{seq}=0$ $0000001 ;$ idno $=3239521.0002 .107 ;$ didno $=3239521.0002 .107$ Accessed April 15, 2011.

[10] L.S. Vygotsky, Mind in Society: The Development of Higher Psychological Processes, M. Cole, V. John- Steiner, S. Scribner, and E. Souberman, eds., Harvard UP, Cambridge, 1978.

[11] A.W. Astin and L.J. Sax, "How Undergraduates Are Affected by Service Participation", Journal of College Student Development, 39:3, pp. 251-263, 1998.

[12] J. Duffy, W. Moeller, D. Kazmer, V. Crespo, L. Barrington, C. Barry and C. West, "Service-learning Projects in Core Undergraduate Engineering Courses", International Journal for Service Learning in Engineering, 3:2, pp. 18-41. 2008.

[13] M. Prentice and G. Robinson, (2010). "Improving Student Learning Outcomes with Service Learning", American Association of Community Colleges, 2010, Available at http://www.aacc.nche.edu/Resources/aac cprograms/horizons/Documents/slorb_ja n2010.pdf Accessed May 1, 2011.

[14] H. Matusovich, D. Follman and W. Oakes, "Work in Progress: A Student Perspective - Why Women Choose Service-learning", $36^{\text {th }}$ ASEE/IEEE Frontiers in Education Conference, $S 2 G$ 7., 2007.

[15] J. Lave and E.Wenger, 1991. Situated Learning: Legitimate Peripheral Participation, Cambridge University Press, Cambridge, 1991. 
[16] J. Lave, "Situating Learning in Communities of Practice", in L. B. Resnick, J.M. Levine, and D.T. Teasley, eds., Perspectives on Socially Shared Cognition, pp.63-82, American Psychological Association, Washington, DC, 1991.

[17] E. Hutchins, "Learning to Navigate", in S. Chaiklin and J. Lave, eds., $\quad$ Understanding Practice: Perspectives on Activity and Context, pp. 35-63, Cambridge University Press, Cambridge, 1993. [18] Y. Engestrom, "Developmental Studies of Work as a Testbench of Activity Theory: The Case of Primary Care Medical Practice, in S. Chaiklin and J. Lave, eds., Understanding Practice: Perspectives on Activity and Context, pp. 64-103, Cambridge University Press, Cambridge, 1993.

[19] T.N. Huckin, "Technical Writing and Community Service", Journal of Business and Technical Communication 11: 1, pp. 49-59, 1997.
[20] D.E. Giles, Jr. and J. Eyler, "The Theoretical Roots of Service-Learning in John Dewey: Toward a Theory of Service Learning", Michigan Journal of Community Service Learning 1:1, pp. 77-85, 1991.

[21] D. Deby, "Ottawa in Transition", Green Living Ottawa, March 7, 2010, http://greenlivingottawa.com/2010/03/07/ ottawa-in-transition/ Accessed March 20, 2011.

[22] Transition Ottawa, http://transitionottawa.ning.com/

Accessed March 20, 2011.

[23] Sustainable Living Ottawa East, "Welcome,"

www.sustainablelivingottawaeast.ca/Web Pages/frames.html Accessed September 10, 2010.

[24] Sustainable Living Ottawa East, "Sustainable Energy and N2N Project," http://www.sustainablelivingottawaeast.c a/WebPages/frames.html Accessed September 10, 2010. 
